\title{
Regional Analysis on Decadal Variation in Aspects of Water Quality in Three Contrasting Coastal Systems of Ishikawa Coast, Japan
}

\author{
J. I. Agboola ${ }^{1,2}$ and A. E. McDonald ${ }^{1}$ \\ ${ }^{1}$ Operating Unit in Ishikawa/Kanazawa, Institute of Advanced Studies, United Nations University, 2-1-1 Hirosaka, Kanazawa, \\ Ishikawa 920-0962, Japan \\ ${ }^{2}$ Department of Fisheries, Faculty of Science, Centre for Environment and Science Education (CESE), Lagos State University, \\ PMB 0001 LASU, Ojo, Lagos, Nigeria
}

Correspondence should be addressed to J. I. Agboola; jb_agboola@yahoo.com

Received 26 December 2012; Accepted 15 January 2013

Academic Editors: C. W. Brown and C.-C. Hung

Copyright (C) 2013 J. I. Agboola and A. E. McDonald. This is an open access article distributed under the Creative Commons Attribution License, which permits unrestricted use, distribution, and reproduction in any medium, provided the original work is properly cited.

\begin{abstract}
This study examines drivers and trends of change in time and space in some coastal water quality parameters and management/cultural practices on the Ishikawa coast, Japan, between 1984 and 2009. Generally, chemical oxygen demand (COD) and dissolved oxygen (DO) concentrations varied significantly $(P<0.001)$ across the three coastal compartments (Kanazawa area (KNA), Noto area (NTA), and Nanao area (NNA)), and pH and DO concentrations varied significantly $(P<0.001)$ over the last three decades, suggesting that human perturbation within the last three decades varied along the coast and may be more relative than environmental change impact. Other water quality variables showed different spatial and temporal patterns and implications across the coastal compartments. Although there is a uniform approach to the development of water quality standards in Japan, these results suggest that setting stricter standards may be required by the prefectural government in collaboration with industry, stakeholders groups, and coastal community resource users.
\end{abstract}

\section{Introduction}

Often, rapid population growth and economic and infrastructural development have caused the large-scale exploitation of coastal resources and resulted in severe degradation and declination of the quality of the coastal environment. Intensive agriculture and coastal engineering, such as artificial inlets, promote some undesirable changes in coastal systems [1]. It is perceived that these pressures on coastal zones will certainly be more intense in the future. Water quality problems in estuaries and coastal areas are currently inserted at a regional scale [2], and continuous field observation data will advance our knowledge of possible future human impact on the coastal environment [3]. Thus, decadal analysis of trends and drivers of change in nearshore ocean ecosystems at regional scale will be required to predict impacts of change in the world's coastal zone.
Stretching along the Sea of Japan, the Ishikawa coast (Figure 1) benefits from a number of diverse and contrasting coastal zone ecosystems exhibiting different physiographic, topographic, and geomorphologic characteristics. From the northern (Noto) to southern (Kaga) districts, a large percentage of Ishikawa's population depends on coastal and marine ecosystems and resources for their livelihoods, and major socioeconomic activities like fisheries, tourism, shipping, and agriculture depend on these resources. The Noto area in particular is acclaimed as one of the largest fisheries development ports in Japan. Over the years, however, the coastline has experienced rapid and serious erosion and coastal habitat loss due to the combined effects of natural and anthropogenic factors [4]. Environmental problems in the marine and coastal areas along the Sea of Japan have been reported to include land-based sources of pollution, oil spills, and coastal alterations including land reclamation and 
excessive groundwater extractions [5-8]. In this study, we found that in the last three decades there were significant spatial and temporal changes in some water quality parameters. Therefore, it is expected that, with the significant spatial differences in land use and human impact along the coast, coastal water quality may continue to degrade in the absence of effective positive policy drive.

Along the Ishikawa coast, patches of documented field water-quality monitoring data date back to 1974 . Here, we evaluate the degree of water quality change on the Ishikawa coast from documented in situ water quality measurements data ( $\mathrm{DO}, \mathrm{COD}, \mathrm{pH}$, temperature, $\mathrm{T}-\mathrm{N}$, and $\mathrm{T}-\mathrm{P}$ ) provided by the Environment Department, Ishikawa Prefectural Office, Japan (Ishikawa Prefecture Annual Report of the Water Quality from Underground Water and Public Water), our field observations, and interviews.

Lastly, the aims of this study were to analyze and document trends of change in some coastal water quality parameters using ground-based data from three contrasting coastal systems of Ishikawa coast and to deduce some natural and anthropogenic drivers of change. From the point of view of water quality, it hopes to explore vulnerable areas on the coast and to document implication of changes on the longterm sustainability of Ishikawa coastal ecosystems.

\section{Study Area Description}

The present study area, Ishikawa coast, is located on the middle north of Japan and lies between $36^{\circ} 17^{\prime} \mathrm{N}$ to $37^{\circ} 52^{\prime} \mathrm{N}$ latitude and between $136^{\circ} 14^{\prime} \mathrm{E}$ to $137^{\circ} 21^{\prime} \mathrm{E}$ longitude (Figure 1). The coastline has a general NE-SW orientation [4], and the coastline has $\sim 581 \mathrm{~km}$ alongshore stretch with significantly different physiographies and topographies from northern (Noto) to southern (Kaga) district. This study area is classified into three coastal compartments based on the significant contrasting physiographic (physical characteristics) changes along the coastline and the need to explore the drivers and mechanisms of change. The first coastal compartmentKanazawa area (hereafter, KNA) - is an exposed bay noted as a large littoral cell stretching approximately $75 \mathrm{~km}$ along the Japan Sea Coast [4] on the southern coast (between south Kaga and Hakui) and features sandy beaches shorelines and strong sea waves of the Sea of Japan. The second coastal compartment is the Noto area (hereafter, NTA), an exposed bay located on the northern coast (between Shika and Noto end of Suzu), dotted with sheer cliffs and unusual rock formations, and also characterized by high and intense sea waves of the Sea of Japan. This coastal compartment (NTA) is acclaimed one of the largest fisheries development ports in Japan. The Nanao area (hereafter, NNA) is the third coastal compartment (from Noto town down to Nanao), a calmer coast facing Nanao Bay blessed with a fine harbor protected against strong south and west winds and has a thriving fishery with an average annual fish catch of approximately 1000 metric tons in recent years. It is an enclosed bay and features both sandy beaches and rocky shorelines.

Generally, Ishikawa's climate is strongly influenced by the Tsushima warm water current and winter wind, causing a wide variety of seasonal environments. It can be described as being humid, wet, and hot in summer and rainy and receiving lots of snow in winter.

\section{Materials and Methods}

This study is based on decadal and comparative analysis of existing records and in situ measurements data of some water quality parameters on the Ishikawa coast, obtained from the Water Quality Monitoring Unit, Environment Department, Ishikawa Prefectural Office, Japan, and from field observations and interviews. Consistent water quality data was available from 33 stations designated-KNA (20), NTA (6), and NNA (7) - and sampled (0-1 m depth) along the coastal zone ( $<5 \mathrm{~km}$ from shoreline) of Ishikawa between 1974 and 2009. Nutrient data were available only at five stations characterized by strong human influence, riverine discharge, and enclosed coastal ecosystems at KNA (2 stations) and NNA (3 stations) coastal compartments. Here, we analyzed for trends and possible drivers of change in some water quality parameters, dissolved oxygen (DO), chemical oxygen demand (COD), an environmental quality standard (EQS) for the conservation of the living environment, and typical water quality indicators for organic contaminant, hydrogen ion concentration $(\mathrm{pH})$, total nitrogen $(\mathrm{T}-\mathrm{N})$, and total phosphate (T-P) on a five-year interval between 1984 and 2009 at the three coastal compartments (KNA, NTA, and NNA).

3.1. Sampling and Analysis. Water samples were collected annually with monthly and station sample size $(n)$ range 10-12 and 30-33, respectively. Temperature, $\mathrm{pH}$, and DO were measured in situ using calibrated portable meters while water samples were analyzed in the laboratory for COD (colorimetric), T-N, and T-P. Nutrient concentrations were measured according to [10] between 1980s and early 90 s immediately after sampling, and from mid-1990s to 2009, nutrient concentrations were measured with Bran and Luebbe Auto Analyser Traacs 800 after storage at $-20^{\circ} \mathrm{C}$.

3.2. Statistical Analysis. Variations in surface water quality parameters (DO, COD, $\mathrm{pH}$, temperature, T-N, and T-P) were compared for the three coastal compartments (KNA, NTA, and NNA) across three decades (between 1984 and 2009) using a two-way analysis of variance (ANOVA), whereas the Duncan multiple range test was used for separation of means. Intercorrelation of variables was investigated using the Pearson product-moment correlations coefficient.

\section{Results}

4.1. Spatial and Temporal Variation in Environmental Variables. Mean annual distribution of rainfall and atmospheric temperature between 1930 and 2010 across the three coastal compartments (KNA, NTA, and NNA) on Ishikawa coast are presented in Figures 2(a) and 2(b). Mean annual rainfall values over the last eight decades showed highly significant $(P<0.001)$ temporal and spatial variation across the Ishikawa prefecture (KNA, NTA, and NNA). The mean annual rainfall 


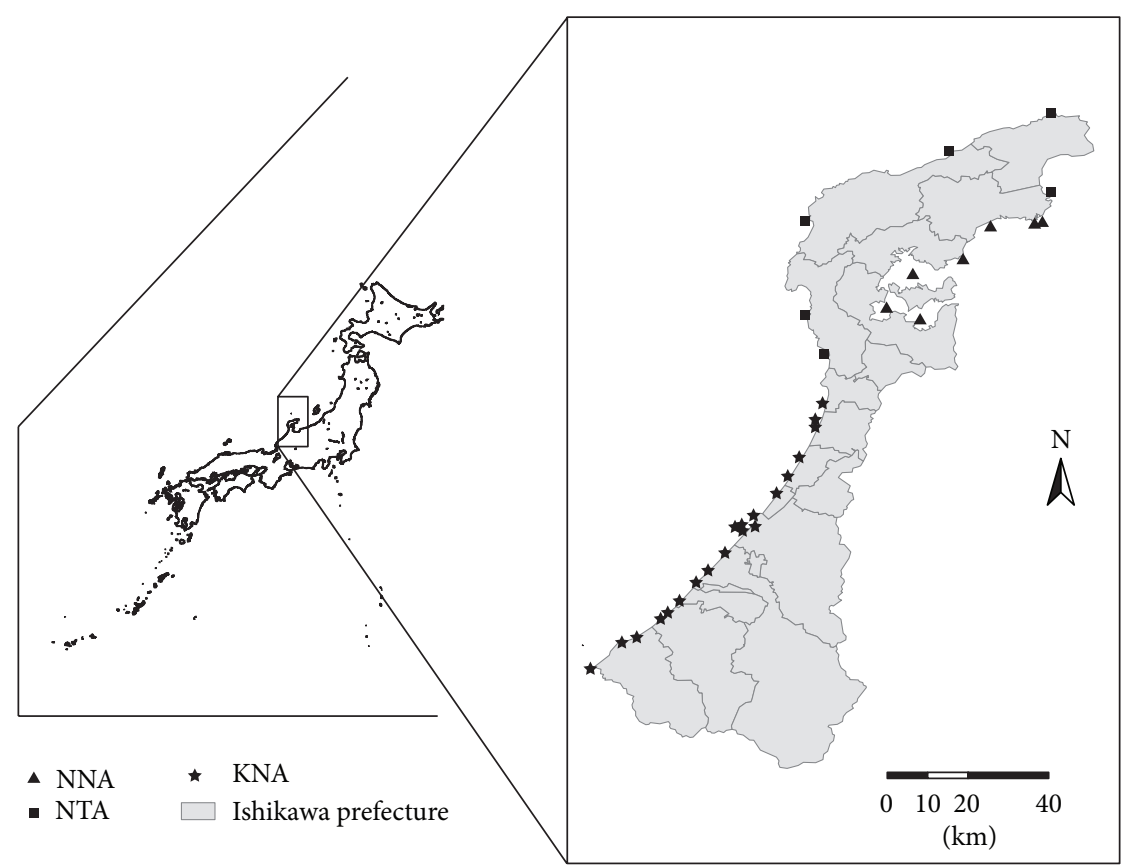

FIGURE 1: Map of study area showing sampling stations at KNA, NTA, and NNA coastal compartments on Ishikawa coast, Ishikawa Prefecture, Japan.

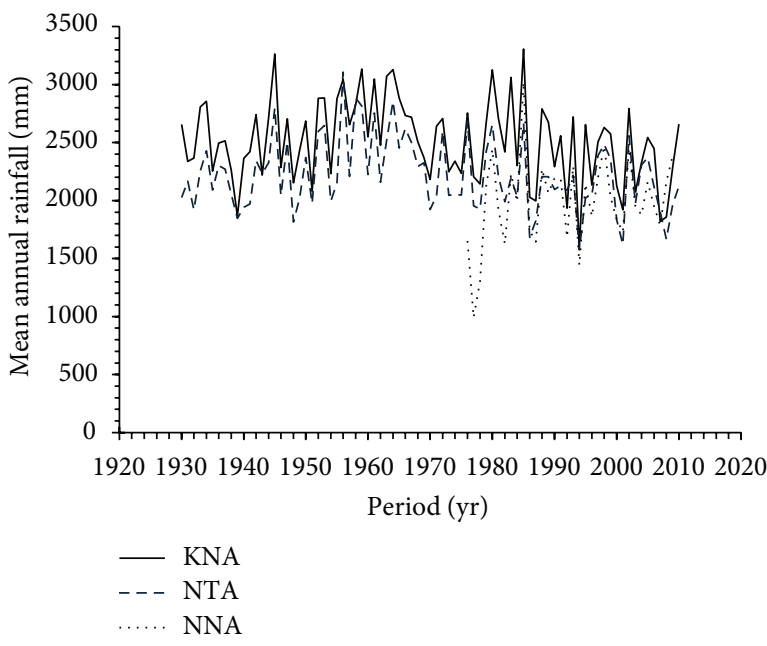

(a)

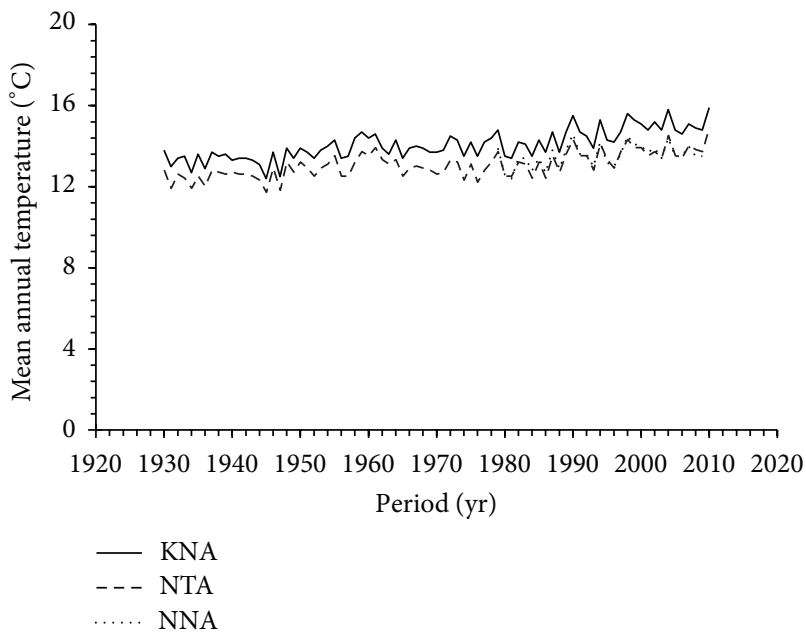

(b)

FIGURE 2: Mean annual rainfall (a) and temperature (b) distribution at KNA, NTA, and NNA coastal compartments on Ishikawa coast between 1930 and 2010.

values (range $1304-3307 \mathrm{~mm}$ ) peaked at KNA $(3307 \mathrm{~mm})$ in 1985 and within the last four decades had minimum value $(1304 \mathrm{~mm})$ recorded at NNA. The mean annual atmospheric temperature increased by $\sim 2.2-3.5^{\circ} \mathrm{C}$ between 1930 and 2010 across the Ishikawa prefecture, and the annual mean temperature maximum $\left(15.9^{\circ} \mathrm{C}\right)$ was recorded in 2010 at NTA. Temporal and spatial analysis revealed highly significant $(P<$ 0.001 ) decadal change in the atmospheric temperature from northern Noto to southern Kaga districts in the Ishikawa prefecture.

\subsection{Water Quality Variables and Values of In Situ Measurements}

4.2.1. Temporal Variation in Water Quality Variables. Annual mean values of water quality variables computed on a fiveyear interval from 1984 to 2009 are shown in Table 1. From ANOVA analysis, water quality variables ( $\mathrm{DO}$ and $\mathrm{pH}$ ) showed highly significant $(P<0.001)$ variation. In the examined years, DO and $\mathrm{pH}$ values showed some marked variations (Figures 3(a) and 3(b)). Along the coast, mean 


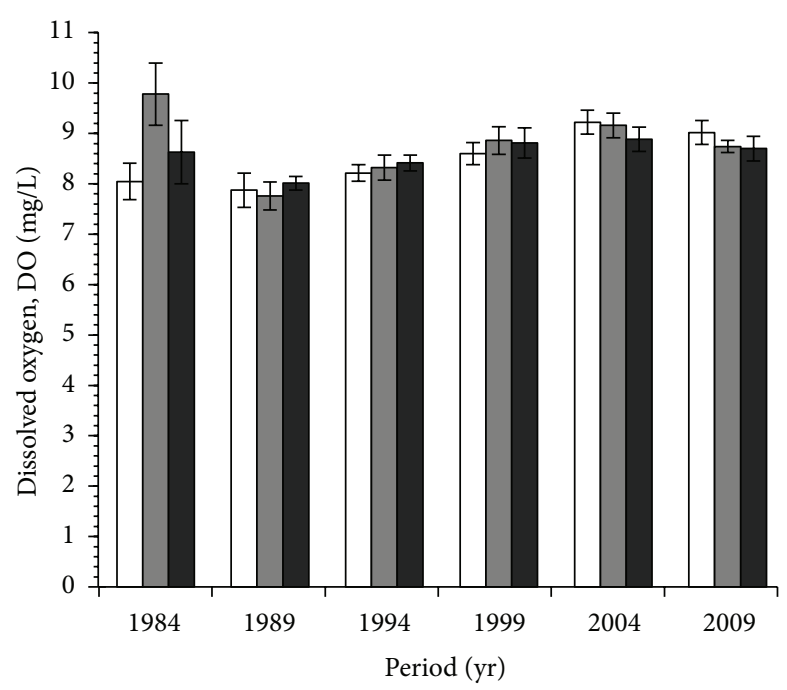

(a)

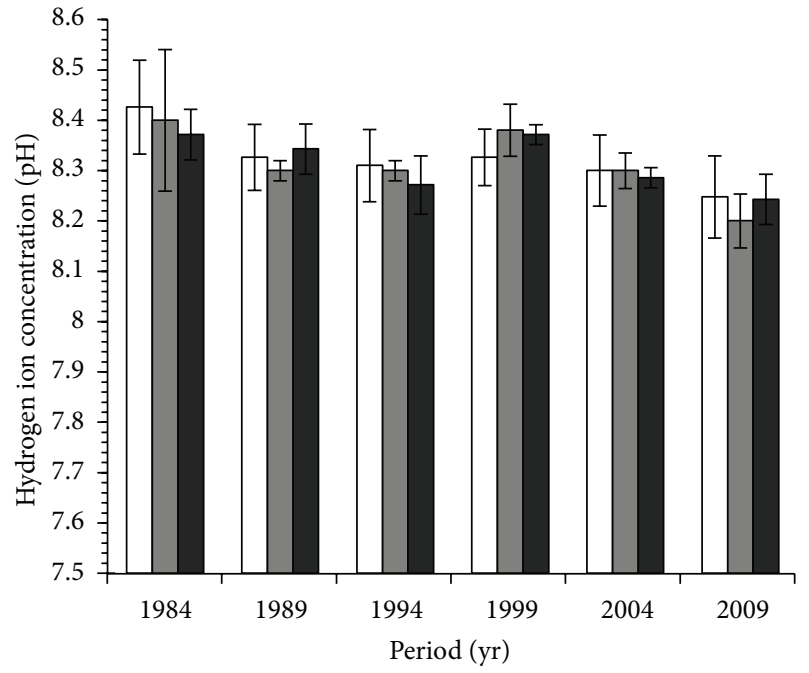

(b)

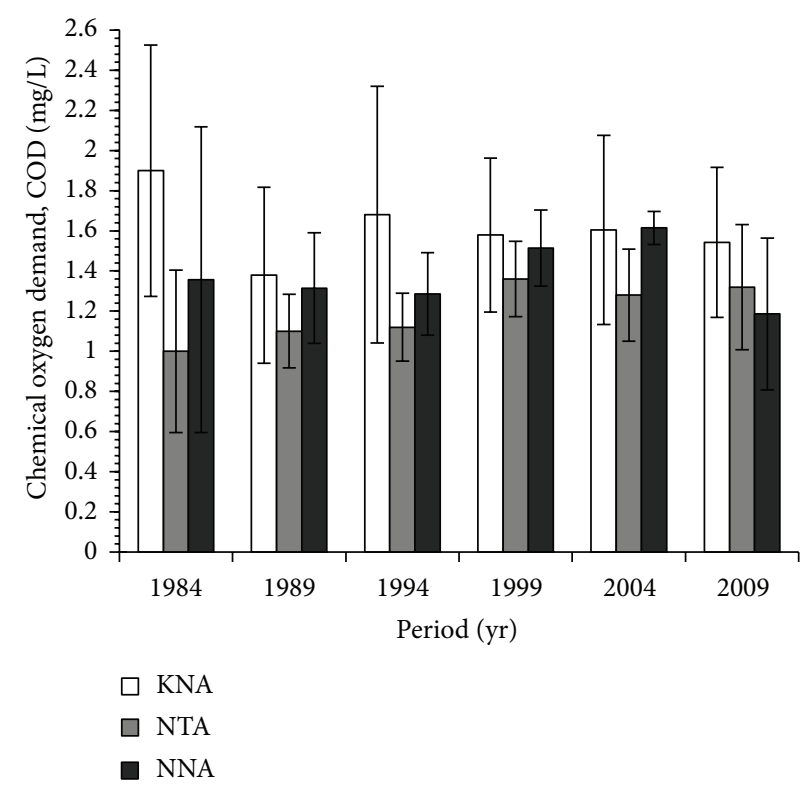

(c)

FIGURE 3: Temporal variation of dissolved oxygen (DO) (a), hydrogen ion concentration (pH) (b), and chemical oxygen demand (COD) (c) at KNA, NTA, and NNA coastal compartments between 1984 and 2009 on Ishikawa coast.

DO values ranged between $7.76 \mathrm{mg} / \mathrm{L}$ (1989) and $9.78 \mathrm{mg} / \mathrm{L}$ (1984) while mean $\mathrm{pH}$ values ranged between 8.20 (2009) and 8.43 (1984), indicating a significant drop ( $~ 0.23$ units) in $\mathrm{pH}$ values within the last three decades. In contrast, the mean concentration of COD was not statistically different $(P>$ $0.05)$ over the years as both maximum $(1.90 \pm 0.63 \mathrm{mg} / \mathrm{L})$ and minimum $(1.00 \pm 0.50 \mathrm{mg} / \mathrm{L}) \mathrm{COD}$ concentrations were recorded in 1984 (Figure 3(c)).

4.2.2. Spatial Variation in Water Quality Variables. Within the last three decades, COD mean concentration has decreased by $\sim 20 \%$ between $1984(1.90 \pm 0.63 \mathrm{mg} / \mathrm{L})$ and $2009(1.54 \pm 0.37 \mathrm{mg} / \mathrm{L})$ at KNA coastal compartment. Similar reduction trend was observed at NNA as mean concentration decreased by $\sim 12 \%$ between $1984(1.35 \pm 0.77 \mathrm{mg} / \mathrm{L})$ and 2009 $(1.19 \pm 0.32 \mathrm{mg} / \mathrm{L})$ (Table 1$)$. In contrast, NTA which had lowest COD concentration in $1984(1.00 \pm 0.50 \mathrm{mg} / \mathrm{L}) \mathrm{had}$ increased by one-fourth $(\sim 25 \%)$ as at $2009(1.32 \pm 0.31 \mathrm{mg} / \mathrm{L})$, possibly as a result of human perturbation from tourism and agricultural and fishing activities. In the years reported in this study, dissolved oxygen concentration spatially varied along the Ishikawa coast, even though maximum $(9.78 \pm 0.62 \mathrm{mg} / \mathrm{L})$ and minimum $(7.76 \pm 0.28 \mathrm{mg} / \mathrm{L})$ DO concentration were recorded at NTA (Figure 3(a)).

Furthermore, in the last three decades, $\mathrm{pH}$ values have dropped between 0.13-0.20 units along the coast (KNA, NTA, and NNA), possibly suggesting environmental change impact on coastal waters quality of Ishikawa. At KNA, maximum $\mathrm{pH}$ 
TABLE 1: Mean \pm SD of some water quality parameters at KNA, NTA, and NNA areas on Ishikawa coast.

\begin{tabular}{|c|c|c|c|c|c|c|c|}
\hline Area & Parameters & 1984 & 1989 & 1994 & 1999 & 2004 & 2009 \\
\hline \multirow{6}{*}{ KNA } & Temperature $\left({ }^{\circ} \mathrm{C}\right)$ & $16.90 \pm 8.1^{\mathrm{a}}$ & $17.77 \pm 7.50^{\mathrm{a}}$ & $19.08 \pm 9.00^{\mathrm{a}}$ & $18.66 \pm 7.80^{\mathrm{a}}$ & $18.95 \pm 8.60^{\mathrm{a}}$ & $19.00 \pm 6.10^{\mathrm{a}}$ \\
\hline & $\mathrm{T}-\mathrm{N}(\mathrm{mg} / \mathrm{L})$ & $0.98 \pm 0.20^{\mathrm{a}}$ & $0.88 \pm 0.20^{\mathrm{a}}$ & $0.79 \pm 0.10^{\mathrm{a}}$ & $0.69 \pm 0.30^{\mathrm{a}}$ & $0.74 \pm 0.20^{\mathrm{a}}$ & $0.65 \pm 0.30^{\mathrm{a}}$ \\
\hline & T-P (mg/L) & $0.09 \pm 0.00^{\mathrm{b}}$ & $0.10 \pm 0.00^{\mathrm{b}}$ & $0.07 \pm 0.00^{\mathrm{a}}$ & $0.05 \pm 0.00^{\mathrm{a}}$ & $0.07 \pm 0.00^{\mathrm{a}}$ & $0.05 \pm 0.00^{\mathrm{a}}$ \\
\hline & $\mathrm{DO}(\mathrm{mg} / \mathrm{L})$ & $8.05 \pm 0.36^{\mathrm{b}}$ & $7.87 \pm 0.34^{\mathrm{a}}$ & $8.22 \pm 0.16^{\mathrm{b}}$ & $8.60 \pm 0.22^{c}$ & $9.22 \pm 0.24^{\mathrm{e}}$ & $9.01 \pm 0.24^{\mathrm{d}}$ \\
\hline & $\mathrm{pH}$ & $8.43 \pm 0.09^{c}$ & $8.33 \pm 0.07^{\mathrm{b}}$ & $8.31 \pm 0.07^{\mathrm{b}}$ & $8.33 \pm 0.06^{\mathrm{b}}$ & $8.30 \pm 0.07^{\mathrm{b}}$ & $8.25 \pm 0.08^{\mathrm{a}}$ \\
\hline & $\mathrm{COD}(\mathrm{mg} / \mathrm{L})$ & $1.90 \pm 0.63^{\mathrm{b}}$ & $1.38 \pm 0.44^{\mathrm{a}}$ & $1.68 \pm 0.64^{\mathrm{a}, \mathrm{b}}$ & $1.58 \pm 0.38^{\mathrm{a}, \mathrm{b}}$ & $1.60 \pm 0.47^{\mathrm{a}, \mathrm{b}}$ & $1.54 \pm 0.37^{\mathrm{a}}$ \\
\hline \multirow{3}{*}{ NTA } & $\mathrm{DO}(\mathrm{mg} / \mathrm{L})$ & $9.78 \pm 0.62^{\mathrm{d}}$ & $7.76 \pm 0.28^{\mathrm{a}}$ & $8.32 \pm 0.25^{\mathrm{b}}$ & $8.86 \pm 0.27^{\mathrm{b}, \mathrm{c}}$ & $9.16 \pm 0.23^{c}$ & $8.74 \pm 0.12^{\mathrm{b}, \mathrm{c}}$ \\
\hline & $\mathrm{pH}$ & $8.40 \pm 0.12^{c}$ & $8.30 \pm 0.00^{\mathrm{b}}$ & $8.30 \pm 0.00^{\mathrm{b}}$ & $8.38 \pm 0.05^{\mathrm{b}, \mathrm{c}}$ & $8.30 \pm 0.00^{\mathrm{b}}$ & $8.20 \pm 0.07^{\mathrm{a}}$ \\
\hline & $\mathrm{COD}(\mathrm{mg} / \mathrm{L})$ & $1.00 \pm 0.50^{\mathrm{a}}$ & $1.10 \pm 0.07^{\mathrm{a}}$ & $1.12 \pm 0.13^{\mathrm{a}}$ & $1.36 \pm 0.13^{\mathrm{a}}$ & $1.28 \pm 0.18^{\mathrm{a}}$ & $1.32 \pm 0.34^{\mathrm{a}}$ \\
\hline \multirow{6}{*}{ NNA } & Temperature $\left({ }^{\circ} \mathrm{C}\right)$ & $20.20 \pm 8.16^{\mathrm{a}}$ & $22.22 \pm 3.98^{\mathrm{a}}$ & $19.62 \pm 7.35^{\mathrm{a}}$ & $21.20 \pm 7.72^{\mathrm{a}}$ & $19.11 \pm 6.38^{\mathrm{a}}$ & $18.36 \pm 7.00^{\mathrm{a}}$ \\
\hline & $\mathrm{T}-\mathrm{N}(\mathrm{mg} / \mathrm{L})$ & $0.28 \pm 0.13^{\mathrm{a}}$ & $0.17 \pm 0.04^{\mathrm{a}}$ & $0.21 \pm 0.04^{\mathrm{a}}$ & $0.29 \pm 0.27^{\mathrm{a}}$ & $0.26 \pm 0.06^{\mathrm{a}}$ & $0.23 \pm 0.06^{\mathrm{a}}$ \\
\hline & T-P (mg/L) & $0.02 \pm 0.01^{\mathrm{a}}$ & $0.03 \pm 0.03^{\mathrm{a}}$ & $0.02 \pm 0.01^{\mathrm{a}}$ & $0.03 \pm 0.03^{\mathrm{a}}$ & $0.05 \pm 0.11^{\mathrm{a}}$ & $0.02 \pm 0.01^{\mathrm{a}}$ \\
\hline & $\mathrm{DO}(\mathrm{mg} / \mathrm{L})$ & $8.63 \pm 0.63^{b, c}$ & $8.02 \pm 0.14^{\mathrm{a}}$ & $8.41 \pm 0.16^{\mathrm{b}}$ & $8.81 \pm 0.30^{\mathrm{b}, \mathrm{c}}$ & $8.89 \pm 0.24^{c}$ & $8.70 \pm 0.25^{b, c}$ \\
\hline & $\mathrm{pH}$ & $8.37 \pm 0.13^{c}$ & $8.34 \pm 0.05^{b, c}$ & $8.27 \pm 0.05^{\mathrm{a}, \mathrm{b}}$ & $8.37 \pm 0.05^{\mathcal{C}}$ & $8.29 \pm 0.04^{\mathrm{a}, \mathrm{b}}$ & $8.24 \pm 0.05^{\mathrm{a}}$ \\
\hline & $\mathrm{COD}(\mathrm{mg} / \mathrm{L})$ & $1.35 \pm 0.77^{\mathrm{a}}$ & $1.31 \pm 0.24^{\mathrm{a}}$ & $1.29 \pm 0.20^{\mathrm{a}}$ & $1.51 \pm 0.20^{\mathrm{a}}$ & $1.61 \pm 0.07^{\mathrm{a}}$ & $1.19 \pm 0.32^{\mathrm{a}}$ \\
\hline
\end{tabular}

Values of respective area and year along the same row bearing the same superscripts are not statistically different at $5 \%$ probability level using the Duncan multiple range test. For each area and year, data (except for T-N and T-P) were pooled from sampling stations ( $n$ size, 30-33) and months $(n$ size, $10-12)$, respectively, to obtain the mean $\pm \mathrm{SD}$. Sea water temperature, T-N, and T-P data were not available for NTA.

value dropped gradually from 8.43 in 1984 to 8.25 in 2009 (Figure 3(b)). Similar trend was observed at NTA and NNA with $\mathrm{pH}$ drop of 0.20 and 0.13 units, respectively, between 1984 and 2009.

In general, while COD and $\mathrm{DO}$ concentrations varied significantly $(P<0.001)$ across the three coastal compartments (KNA, NTA, and NNA), there was no significant variation $(P>0.05)$ in $\mathrm{pH}$ along the coast. Also, while $\mathrm{pH}$ and DO concentrations varied significantly $(P<0.001)$ over the last three decades, there was no significant $(P>0.05)$ change in COD concentration (Figure 3(c)), suggesting that human perturbation over the years may be more relative than environmental change impact.

\subsubsection{Spatial and Temporal Variation of Nutrient Concen-} trations and Temperature. The range of nutrients (T-N and $\mathrm{T}-\mathrm{P})$ concentration and sea water temperature within the last three decades at KNA and NNA is presented in Table 1. Nutrients concentration and seawater temperature profile across the examined periods were relatively homogenous in the two coastal compartments. An exception is T-P nutrient concentration at KNA. Mean values recorded over the years were not statistically different at $5 \%$ probability level using the Duncan multiple range test. While total nitrogen (T-N) and total phosphate (T-P) loading have significantly reduced by $\sim 30-45 \%$ between 1984 and 2009 at KNA, there has not been significant reduction at NNA, suggesting a coastal system potentially vulnerable to eutrophication possibly due to often restricted water exchange with the adjacent ocean, river runoff, and shore and/or shallow sediment abrasion. Also, the relationship between T-N and T-P and their distribution along the Redfield ratio line $(\mathrm{N}: \mathrm{P}=16: 1)$ at $\mathrm{KNA}$ and NNA is shown in Figures 4(a) and 4(b). Corresponding T-N and T-P values were distributed often above the Redfield ratio line at KNA and around (above and below) the Redfield ratio line at
TABLE 2: Pearson's correlation matrix of some water quality parameters at KNA, NTA, and NNA on Ishikawa coast.

\begin{tabular}{lccccc}
\hline & $\mathrm{DO}$ & $\mathrm{pH}$ & $\mathrm{COD}$ & Year & Area \\
\hline $\mathrm{DO}$ & 1 & & & & \\
$\mathrm{pH}$ & -0.086 & 1 & & & \\
$\mathrm{COD}$ & 0.066 & $0.359^{* *}$ & 1 & & \\
Year & $0.548^{* *}$ & $-0.502^{* *}$ & -0.026 & 1 & \\
Area & 0.107 & 0.012 & $-0.249^{* *}$ & -0.016 & 1 \\
\hline
\end{tabular}

${ }^{* *}$ Correlation is significant at the 0.01 level (2-tailed).

NNA. These distribution patterns of nutrient concentration suggest some potential limitation of T-N nutrient at KNA and T-P nutrient at NNA. Nutrient-flux ratio (N:P ratio) distribution at KNA and NNA exhibited annual fluctuations (Figure 5) with ratio values exclusively $<16: 1$ at KNA (N/P min: 6.0; N/P max: 15.8). Although $\mathrm{N}$ : $\mathrm{P}$ ratios varied widely and are largely distributed close to the $16: 1$ at NNA, optimal algal growth ratio as indicated by the Redfield ratio [9].

4.2.4. Intercorrelation of Spatial and Temporal Water Quality Variables. The intercorrelation among water quality variables $(\mathrm{pH}, \mathrm{COD}$, and $\mathrm{DO})$ in relation to the examined periods and coastal compartments (Table 2) revealed a significant positive correlation $(r=0.359 ; P=0.001 ; n=191)$ between $\mathrm{pH}$ and COD. Across the examined years, DO showed a positive and highly significant correlation $(r=0.548$; $P=$ $0.001 ; n=191)$, whereas $\mathrm{pH}$ showed a negative and highly significant correlation $(r=-0.502 ; P=0.001 ; n=191)$, suggesting that while $\mathrm{pH}$ value has decreased significantly over the years, $\mathrm{DO}$ has been on the increase. Of the water quality variables $(\mathrm{pH}, \mathrm{COD}$, and $\mathrm{DO})$ only $\mathrm{COD}$ showed a significant negative correlation $(r=-0.249 ; P=0.01 ; n=$ 191 ) with the three coastal compartments. Using the Pearson 


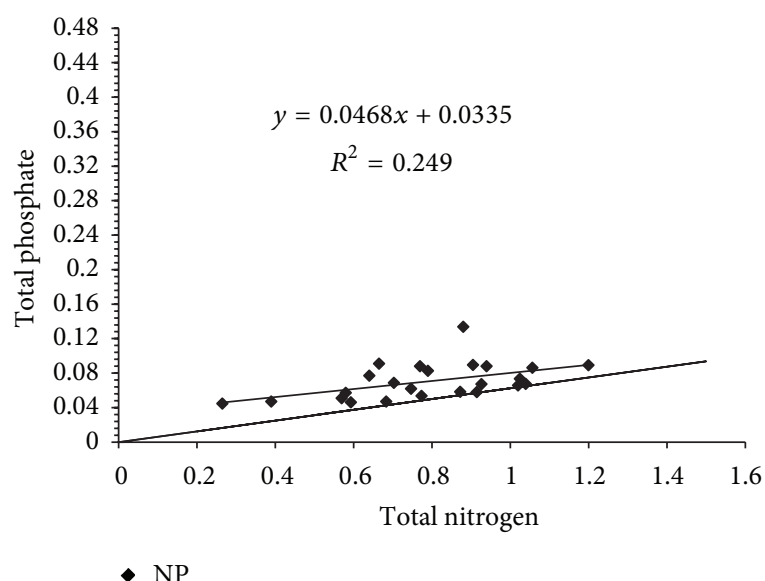

(a)

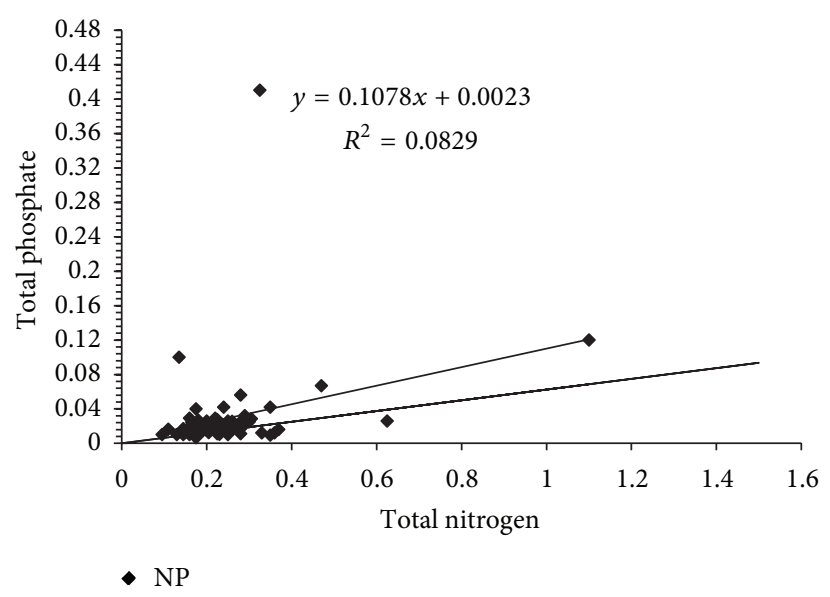

(b)

Figure 4: Relationship between T-N and T-P at KNA (a) and NNA (b) coastal compartments between 1984 and 2009 on Ishikawa coast. Dark thin line is linear regression and dark thick line is the Redfield et al. [9] ratio $(\mathrm{N}: \mathrm{P}=16: 1)$.

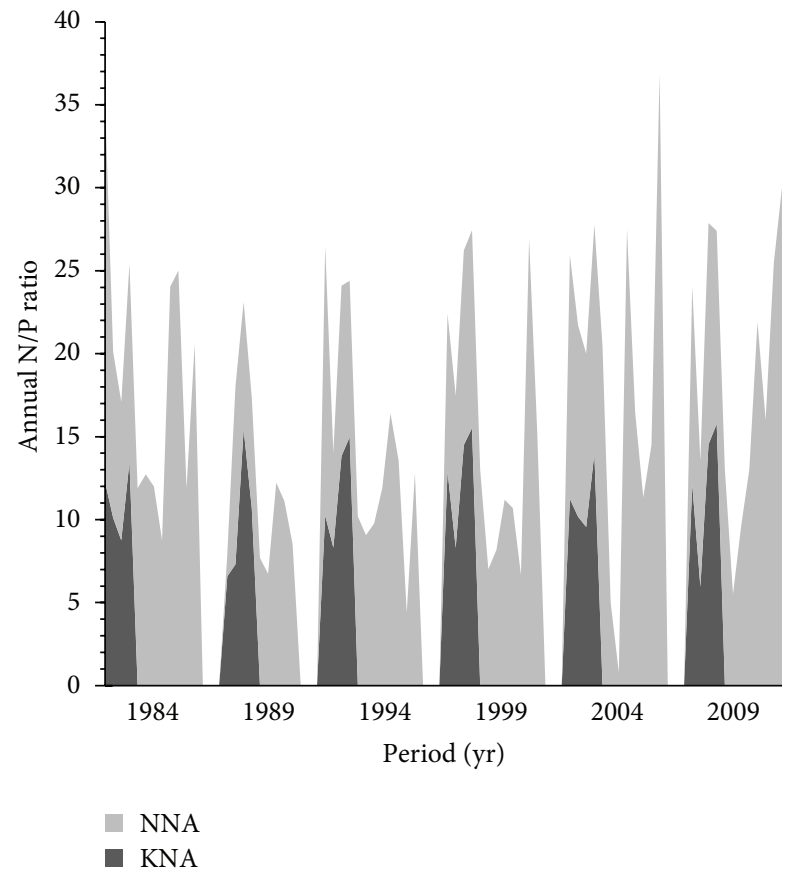

FIGURE 5: N : P molar ratio distribution at KNA and NNA coastal compartments between 1984 and 2009.

product moment correlations coefficient (table not shown), we further elucidate on the dynamics of water quality change at the different coastal compartments. At KNA, DO showed an increasing and highly significant $(r=0.810 ; P=0.0001$; $n=119)$ trend over the years and significantly correlated $(r=0.222 ; P=0.05 ; n=119)$ with COD, whereas, at NTA, there was no significant correlation with COD and over the years. While DO showed a less significant $(r=0.374$; $P=0.05 ; n=42)$ increase over the years at NNA, there was no significant correlation with COD. Spatially, COD showed a positive significant correlation $(r=0.420 ; P=0.05$; $n=30$ ) only at NTA, suggesting an increasing trend over the years. Highly significant correlation of $\mathrm{DO}$ and $\mathrm{pH}$ variables over the years suggests their relative importance to decadal variation on Ishikawa coast towards predicting current state and future status of coastal water quality that may require policy response. Since only COD showed significant correlation with the three coastal compartments, it suggests that human impacts vary along the coastline and warrants further investigation, local attention, and adequate policy response.

\subsubsection{Intercorrelation of Nutrient Concentration and Temper-} ature at KNA and NNA. We evaluate the relations between T-N, T-P, and temperature variables using Pearson product moment correlations coefficient. Temporally, there was highly significant correlations $(r=0.467 ; P=0.0001 ; n=93$ ) between T-N and T-P, whereas no significant relationship was established between temperature and nutrients over the examined period when data from the two coastal compartments (KNA and NNA) were pooled for Ishikawa coast (Table 3). However, a negative highly significant correlation $(r=-0.676 ; P=0.0001 ; n=24)$ was observed between temperature and T-N. Also, there was significant inverse correlation of T-N $(r=-0.490 ; P=0.01 ; n=24)$ and T-P $(r=-0.708 ; P=0.0001 ; n=24)$ with KNA coastal compartment (table not shown). All these suggest that nutrients' loading on Ishikawa coast has decreased over the years; however, further monitoring may be required at NNA, an enclosed coastal compartment.

\section{Discussion}

Results from this study on regional analysis of decadal variations in water quality along Ishikawa coasts revealed some level of significant $(0.0001 \geq P \leq 0.05)$ changes across space and time in some water quality variables. Observed spatial pattern indicates that coastal developments, varying levels of socioeconomic activities, and perhaps physical processes, 
TABLE 3: Pearson's correlation matrix of nutrients and temperature at KNA and NNA on Ishikawa coast.

\begin{tabular}{lccccc}
\hline & Temperature & T-N & T-P & Year & Area \\
\hline Temperature & 1 & & & & \\
T-N & -0.172 & 1 & & & \\
T-P & 0.055 & $0.467^{* *}$ & 1 & & \\
Year & -0.057 & -0.096 & -0.024 & 1 & \\
Area & 0.105 & $-0.832^{* *}$ & $-0.386^{* *}$ & 0.017 & 1 \\
\hline${ }^{* *}$ Correlation is significant at the 0.01 level (2-tailed). & &
\end{tabular}

such as water residence time, shore, and/or shallow sediment abrasion, river runoffs, and climate change, are factors that play an important role in promoting change in the coastal zone. Due to the influences of human activities, within only a few decades, numerous previously pristine, oligotrophic estuarine, and coastal waters have undergone a transformation to more mesotrophic and eutrophic conditions [11-13], promoting space-time variation in water quality.

Over the last eight decades (1930-2010), mean annual rainfall and atmospheric temperature revealed a highly significant $(P<0.0001)$ decadal change and dynamic spatial pattern from northern Noto (NTA and NNA) to southern Kaga (KNA) districts in Ishikawa prefecture. As a result, a general description of the Ishikawa coastal climate may be complex and may partly influence the spatial dynamics in some water quality parameters.

Chemical oxygen demand (COD), a typical water quality indicator for organic contaminant and an environmental quality standard (EQS) for the conservation of the living environment, revealed more of a spatial than temporal variation on the Ishikawa coast. For instance, COD maximum (1.90 \pm $0.63 \mathrm{mg} / \mathrm{L})$ and minimum $(1.00 \pm 0.50 \mathrm{mg} / \mathrm{L})$ concentrations were recorded, respectively, at KNA and NTA in 1984. Similar trend was observed in other years, suggesting that spatial variation pattern was more significant on the Ishikawa coast possibly due to differences in human perturbation levels. Only COD water quality variable showed significant correlation (at $1 \%$ probability level) with the three coastal compartments (Table 3), suggesting that anthropogenic impacts vary along the coastline and may warrant further investigation and adequate policy response. Thus, variations in organic contamination pattern is rather spatial than temporal along the Ishikawa coast and may have implication on coastal living resources.

5.1. Ecological Response to DO, $p H$, and Nutrients. Generally, surface DO concentrations varied significantly $(P<0.001)$ over the last three decades and across the three coastal compartments (KNA, NTA, and NNA). Decrease in DO concentration as observed between 2004 and 2009, especially at KNA and NNA, was hypothesized to be driven primarily by changes in ocean circulation and less by changes in the rate of $\mathrm{O}_{2}$ demand from downward settling of organic matter since there was a corresponding decrease in COD concentration. On the Japan Sea, [14] report a large long-term decrease in the oceanic $\mathrm{O}_{2}$ concentration of more than $20 \mu \mathrm{mol} \mathrm{kg}-1$ since the mid-1950s. [15] analyzed GEOSECS and WOCE data to calculate basin-wide changes for the North Pacific. They find a decrease in dissolved $\mathrm{O}_{2}$ in the upper ocean and an increase in the deep. Decreasing $\mathrm{O}_{2}$ concentrations were also reported by $[16,17]$ in subsurface water in the western subarctic Pacific between 1968 and 1998, and by [18], analyzing data of four different cruises in the North Pacific during the 1980s and 1990s. The observation-based analyses identify ocean circulation changes as the main cause of the observed decrease in dissolved $\mathrm{O}_{2}$ [14-20].

Although near-surface changes in $\mathrm{O}_{2}$ concentration are difficult to interpret as observed changes cannot be explained by known processes, changes in $\mathrm{O}_{2}$ can be caused by changes in biological activities, changes in the physical transport of $\mathrm{O}_{2}$ from intermediate waters, or by changes in temperature and salinity [21]. In this study, possible influence of temperature on $\mathrm{O}_{2}$ solubility was not considered since there is no significant correlation $(P>0.05)$ between temperature and $\mathrm{O}_{2}$. Also, we lacked data to suggest the possible influence of phytoplankton activity on dissolved oxygen. Along the Ishikawa coast, dissolved oxygen (DO) concentrations were significantly higher than $5.0 \mathrm{mg} / \mathrm{L}$ suggested as acceptable for most aquatic organisms [22]. Also, according to [23], environmental dissolved oxygen levels must be high enough to support aerobic metabolism in fishes. Thus, the DO concentration obtained from this study suggests that the coastal ecology of Ishikawa could support growth and reproduction of living resources as observed in the thriving fishery industries along the coastline, especially at NTA and NNA.

Within the last three decades, trend analysis showed that hydrogen ion concentration $(\mathrm{pH})$ value has dropped between 0.13-0.20 units along the coast (KNA, NTA, and NNA) and $\sim 0.23$ units between 1984 and 2009, leading to an increase in water column acidity and suggesting possible environmental change impact on coastal water quality of Ishikawa. While phytoplankton activity may strongly influence $\mathrm{pH}$, we consider that most marine plants (with the exception of seagrasses) are carbon-saturated [24], and enhanced growth is not expected. Increased $\mathrm{CO}_{2}$ concentrations lower ocean $\mathrm{pH}$, which in turn changes ocean carbonate chemistry [25], and it is believed that this resulting decrease in $\mathrm{pH}$ will have negative consequences, primarily for oceanic calcifying organisms. When compared with physically driven changes such as warming and sea level rise, the impacts of chemical changes in the ocean are poorly understood. While increases in $\mathrm{CO}_{2}$ are expected to have positive impacts on many terrestrial plants because of increases in photosynthesis [26], as earlier mentioned, the reverse may be for carbon-saturated marine plants [24]. However, the reduction in $\mathrm{pH}$ that will accompany elevated $\mathrm{CO}_{2}$ concentrations has profound implications for physiological processes in marine organisms. For example, growth and survivorship of gastropods and urchins were reduced when exposed to 6 months of increased $\mathrm{CO}_{2}$ that resulted in only a $\mathrm{pH}$ unit decrease of only 0.03 [27]. Also, the population and community level impacts of such changes remain largely unknown. Considering that the expected $\mathrm{pH}$ drop may be unprecedented over the last several hundred million years and as evident also along Ishikawa coast, more research on ecological implications of $\mathrm{pH}$ change is needed. In relation to human health, however, hydrogen ion 
$(\mathrm{pH})$ has a direct impact on the recreational users of water only at very low or very high values [28].

Furthermore, according to [21], changes in nutrient concentrations can provide information on changes in the physical and biological processes that affect the carbon cycle and could potentially be used as indicators for large-scale changes in marine biology. Although there was a significant reduction in nutrients concentration at KNA coastal compartment than at NNA coastal compartment, nutrients fluxes are significantly (T-N: $r=-0.832 ; P=0.0001 ; n=93$, TP: $r=-0.386 ; P=0.0001 ; n=93$ ) higher at KNA than at NNA. Since most nitrogen loading into aquatic systems has often been implicated with anthropogenic influence and sometimes physical forcing, drivers of nutrient fluxes along the Ishikawa coast especially at KNA may be due to increasing socioeconomic activities and population growth over the years. Nutrient impacts on coastal waterways vary as a function of both the loadings (fluxes) and bioavailability of the nutrients and the extent to which hydrodynamic features (e.g., water volumes, residence times, and extent of mixing) and turbidity levels modulate the stimulatory effects of nutrients on plants and algae [29,30]. Here, results of regression analysis carried out to further establish the relationship of nutrients (T-N and T-P) with physical forcing such as temperature at KNA and NNA coastal compartments revealed that temperature significantly correlated with nutrients concentration especially T-N $(r=0.438 ; P=0.0003$; $n=24$ ) at KNA (figure not shown) while at NNA, there was no significant correlation with nutrient T-N $(r=0.006$; $P=0.244 ; n=69)$. We hypothesize that other factors than physical forcing may impact on nutrients concentration and, thus, foreground the need to determine the effect of anthropogenic forcing on water quality along the Ishikawa coast.

\subsection{Possible Drivers of Change in Coastal Water Quality.} Increasing human pressure on the continental margins with expanding urbanization and the conflicting demands of tourism, aquaculture, water diversions, wind parks, and other developments such as ports have been well documented as drivers of change in coastal ecosystems $[3,4,31,32]$. Ishikawa coast has experienced significant erosion in recent 100 years due to the combined effect of natural and artificial causes; the shoreline retreats about $200 \mathrm{~m}$ from 1892 to 1970 [33]. As countermeasures against erosion problems, construction of detached or submerged breakwaters started in 1970 with increased intensity from the mid-1970s to the late 1980. By the mid-1990s almost the entire stretch was protected by this structure [4].

Along KNA coastal compartment, major coastal threat is beach erosion. Erosion is advancing and the sandy beach is rapidly disappearing, thus, becoming a large social problem in Ishikawa. In this study, most of the nutrient concentrations show high levels in southern coastal plain at KNA for the following reasons. First, the SW and SS shoreline cities like Kanazawa, Hakusan, and Komatsu are densely populated with sizeable industrial centers relative to NTA and NNA coastal compartments; second, as mentioned earlier, the coast has experienced rapid and serious erosion due to the combined effects of natural and anthropogenic factors [34]; third, the annual net alongshore sediment transport is from NE to the SW near the KNA shoreline [33] and the development of Kanazawa Port. Around NTA coastal compartment, refuse abandonment on the coast by tourist has been identified as one of the drivers of change in the coastal water quality. In the wave of enormous quantity of refuse on the coast especially along Shioya to Sogogi coast at NTA, community involvement in coastal cleanup was launched and has since been sustained.

In addition, coastal ecosystems like the NNA coastal compartment may be particularly vulnerable to eutrophication due to often restricted water exchange with the adjacent ocean and river runoffs, leading to an accumulation of nutrients from the surrounding watershed [1]. Marine environments subjected to eutrophication are usually those with limited mixing capacity. The process of eutrophication is usually rather slow and location specific, and because eutrophication generally stems from nonpoint sources, the process may be difficult to legislate and control. Eutrophication of coastal waters can have a number of adverse impacts on ecosystems, including algal growth, hypoxia, and substantial loss of marine life and habitat [31].

Thus, the main vulnerable areas of the coast, from the water quality point of view, seem to be the KNA coastal compartments, where high COD concentrations and nutrients (T-N and T-P) concentrations are observed. Although, COD concentration has been the lowest at NTA relative to KNA and NNA, increasing trend observed at NTA in recent years (Figure 5 and Table 1 ) suggests some form of organic contamination possibly as a result of anthropogenic influence which may warrant further investigation and local attention.

In general, surface coastal water quality has improved with respect to some pollutants and nutrient loading in Japan as well as Ishikawa's ocean coastline. However, nutrient loading especially in semienclosed bay like the NNA is a potential site for eutrophication.

\subsection{Coastal Pollution Problems (Past and Present Status) and} Policy Response. Despite the apparent declines in coastal environmental quality in Ishikawa, in Japan overall, the number of confirmed sea pollution cases declined by $82 \%$ from 2460 (of which 2060 are oil-related) in 1973 to 425 in 2004 [35], and as reported by the Japan Coast Guard (Figure 6). Although specific data for Ishikawa prefecture is not reported here, it is assumed that this reported trend cuts across Japan.

This decreasing trend of sea pollution has been achieved through various programmes since the Marine Pollution Prevention Law was enacted in 1970. The discharge of noxious liquid substances by ocean-bound vessels has been regulated by a national law, which corresponds to the Protocol of 1978 relating to the international convention for the prevention of pollution from ships (the Marpol 73/78 protocol). Also, a water pollution control law has been enhanced and includes a system to notify specified facilities, wastewater regulation common to the whole country; continuous monitoring of water quality; a Total Pollutant Load Control System (TPLCS) for closed sea areas and measures for domestic effluent. 


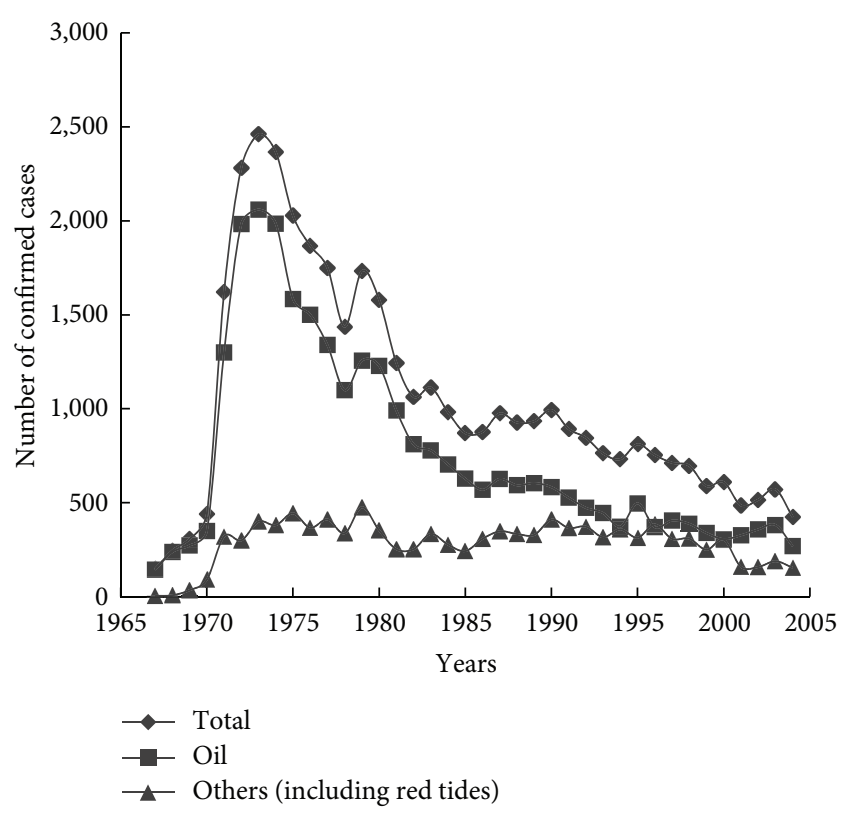

FIgURE 6: Confirmed cases of sea pollution in Japan (data source: Japan Coast Guard, Ministry of Environment).

More recently, in 2008, Japan's Ministry of Environment (MOE) launched the Japan Sea Satoumi Policy Initiative, working with local municipalities and prefectural and regional government officials. Ishikawa's Nanao Bay (NNA coastal compartment in this study) has been selected as one of the four official sites chosen for the Satoumi Pilot Project. Then in early 2011, MOE formulated the Satoumi Guidelines to aid in the implementation of a national strategy for "creation of vibrant local communities that make use of natural resources." One of the main components of this strategy includes the "development of abundant Satoumi areas" and other related targets such as conservation, restoration, and creation of seagrass beds and tidal flats; water pollution measures; and sustainable resource management.

Satoumi has been defined as coastal areas with high productivity and biodiversity enhanced through human management. It has long sustained not only productive and distribution activities, but also a rich cultureal and intercultural exchange and are characterized by rich productivity and biodiversity. The integrated management of terrestrial and coastal areas characteristic of Satoumi has contributed immensely to maintaining material cycle functions and, thus, rich and diverse ecosystems and their services.

In Japan, environmental quality standards (EQS) relating to living environment, including standards for biochemical oxygen demand (BOD), chemical oxygen demand (COD), and dissolved oxygen (DO), have been established for coastal water pollution. From this study, Figures $7(a), 7(b)$, and $7(c)$ show the variations of COD, DO, and $\mathrm{pH}$ values from Japan's EQS at KNA, NTA, and NNA coastal compartments. While we consider the dissolved oxygen (DO) a plus, being relatively higher than Japan's minimum set standards, the COD concentration slightly close to the maximum set standard may require further attention and monitoring. Hydrogen ion concentration $(\mathrm{pH})$ was slightly higher than maximum set standards and may also require further monitoring to advance our understanding on possible implication. It is hoped that findings from this study will help to promote local, regional, and national policy towards conservation and sustainable management of coastal water quality and resources by solving the problem of alienation of humans from the sea-a challenge to Satoumi.

Finally, water quality policy, which reflects dynamic social values and scientific understanding, should evolve flexibly to reflect the local context too. Thus, based on the dynamic spatial characteristics of Ishikawa coastline, decision makers should ensure that Ishikawa's coastal planning/zoning accommodates livelihood and economic changes that accompany changing biodiversity and fishing regimes, sea-level rise, and erosion. Although there is a uniform approach to the development of water quality standards in Japan, stricter standards may be required by prefectural governments in collaboration with industry, stakeholders groups, and coastal community resource users. For such strategies to be most effective in maintaining coastal water quality, continuous monitoring of coastal developments and activities should take place.

\section{Conclusion}

Monitoring programs of aquatic systems play a significant role in water quality control since it is necessary to know the contamination degree so as not to fail in the attempt to regulate its impact [32]. Documenting long-term changes of regional coastal ecosystems like the Ishikawa coastal zones may be an effective management strategy for sustainable aquatic resource management under current and potential future global environmental change effects. Results obtained from this water quality analysis revealed and further buttressed variability and unsteadiness as intrinsic properties of coastal ecosystems, where the action of natural forcing factors is difficult to isolate from anthropogenic ones. While this study did not provide a water quality assessment or an overall process of evaluation of the physical, chemical, and biological nature of water in relation to natural quality and human effects, it has helped to define current conditions, established trends on Ishikawa coasts and provided information on vulnerable area along the coast from view point of water quality to enable further investigation and possible prefectural or local government response. Effective waterquality monitoring requires actual collection of information at set locations and at regular intervals in order to provide the data which may be used to define current conditions and establish trends. An attempt, therefore, to maintain the coastal water quality through continuous monitoring of coastal developments and activities will be a more targeted and effective adaptation strategy.

Further studies to this will detail on the socioeconomic drivers of current findings, and environmental change impacts on Ishikawa's coastal living resources majorly at KNA and NNA, and policy response required for future decision making. 


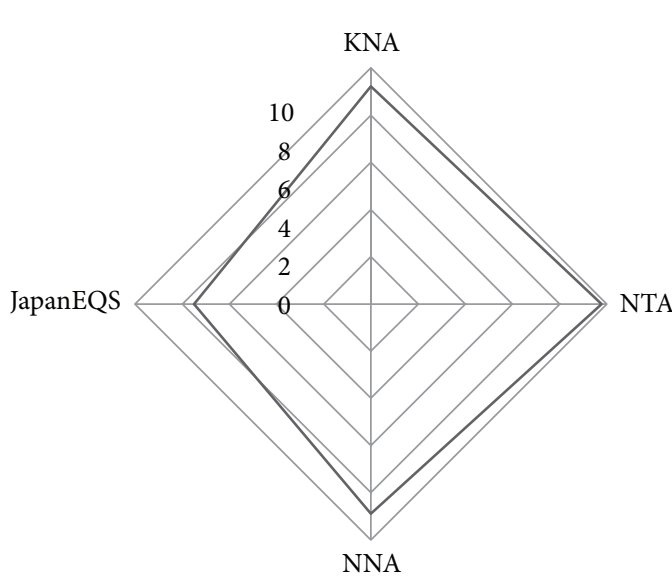

(a)

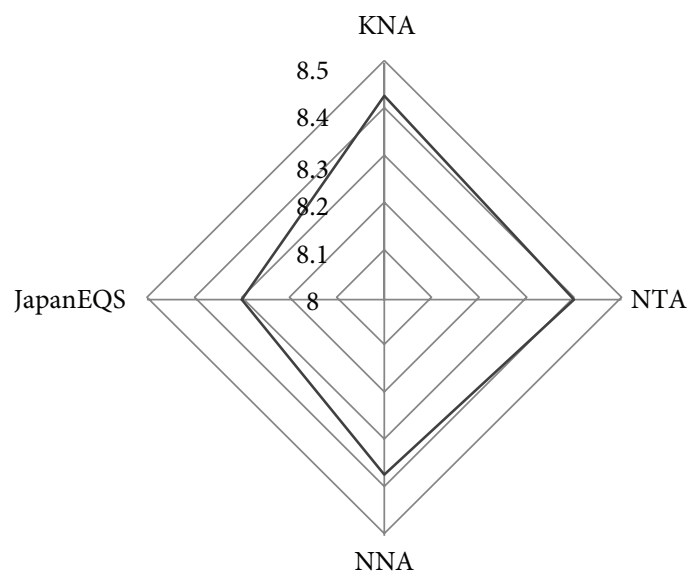

(b)

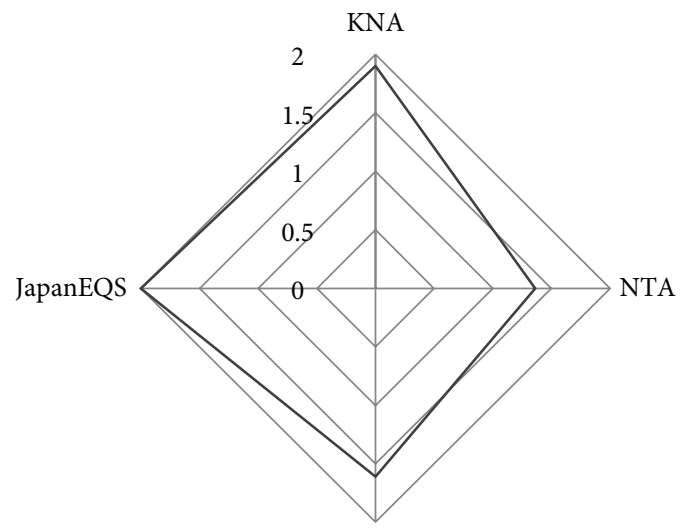

NNA

(c)

FIGURE 7: Radar diagram of Japan's environmental quality standards (JapanEQS) in relation to maximum DO (a), pH (b), and COD (c) at KNA, NTA, and NNA coastal compartments on Ishikawa coast between 1984 and 2009.

\section{Acknowledgments}

In situ water quality data used in this study was made possible by the long-term water-quality monitoring programme of the Environment Unit, Ishikawa Prefectural Office, Japan. The authors appreciate the assistance of Ms. Akemi Kubota, an intern with the UNU IAS OUIK, for extracting the data and staff members-Laura Cocora and Atsuko Hasegawa-for the translation of some historical information.

\section{References}

[1] F. U. González, J. A. Herrera-Silveira, and M. L. AguirreMacedo, "Water quality variability and eutrophic trends in karstic tropical coastal lagoons of the Yucatán Peninsula," Estuarine, Coastal and Shelf Science, vol. 76, no. 2, pp. 418-430, 2008.

[2] J. F. Lopes, J. M. Dias, A. C. Cardoso, and C. I. V. Silva, “The water quality of the Ria de Aveiro lagoon, Portugal: from the observations to the implementation of a numerical model," Marine Environmental Research, vol. 60, no. 5, pp. 594-628, 2005.
[3] J. I. Agboola, M. Uchimiya, I. Kudo, K. Kido, and M. Osawa, "Dynamics of pelagic variables in two contrasting coastal systems in the western Hokkaido coast off Otaru port, Japan," Estuarine, Coastal and Shelf Science, vol. 86, no. 3, pp. 477-484, 2010.

[4] M. Yuhi, S. Umeda, and K. Hayakawa, "Regional analysis on the decadal variation of sediment volume in an integrated watershed composed of the Tedori river and the Ishikawa Coast, Japan," Journal of Coastal Research, Special Issue, vol. 56, pp. 1701-1705, 2009.

[5] K. Tazaki, "Heavy oil spilled from Russian tanker "Nakhodka" in 1997: towards eco-responsibility, earth sense," in 21st Century COE Kanazawa University, Kanazawa University Press, Kanazawa, Japan, 2003.

[6] S. K. Chaerun, K. Tazaki, R. Asada, and K. Kogure, "Bioremediation of coastal areas 5 years after the Nakhodka oil spill in the Sea of Japan: Isolation and characterization of hydrocarbondegrading bacteria," Environment International, vol. 30, no. 7, pp. 911-922, 2004.

[7] T. Nakamura, "Identification and prioritisation of marine environmental problems in the Sea of Japan and strategic planning for addressing them.," in Proceedings of the 1st Meeting of Experts and National Focal Points (NFPs) on the 
Development of the Northwest Pacific Action Plan (NOWPAP), pp. 28-31, Centre for International Projects and the Pacific Oceanological Institute, Vladivostok, Russia, 2004, http://www .unep.ch/regionalseas/pubs/profiles/nowpap.doc.

[8] K. Hayakawa, M. Nomura, T. Nakagawa et al., "Damage to and recovery of coastlines polluted with C-heavy oil spilled from the Nakhodka," Water Research, vol. 40, no. 5, pp. 981-989, 2006.

[9] A. C. Redfield, B. H. Ketchum, and F. A. Richards, "The influence of organism on the composition of seawater," In the Sea, vol. 2, pp. 26-77, 1963.

[10] T. R. Parsons, Y. Maita, and C. M. Lalli, A Manual of Chemical and Biological Methods for Seawater Analysis, Pergamon Press, New York, NY, USA, 1984.

[11] S. W. Nixon, "Coastal eutrophication: a definition, social causes, and future concerns," Ophelia, vol. 41, pp. 199-220, 1995.

[12] H. W. Paerl, "Coastal eutrophication and harmful algal blooms: Importance of atmospheric deposition and groundwater as 'new' nitrogen and other nutrient sources,' Limnology and Oceanography, vol. 42, no. 5, pp. 1154-1165, 1998.

[13] C. J. Gobler and G. E. Boneillo, "Impacts of anthropogenically influenced groundwater seepage on water chemistry and phytoplankton dynamics within a coastal marine system," Marine Ecology Progress Series, vol. 255, pp. 101-114, 2003.

[14] K. R. Kim, K. Kim, D. J. Kang et al., "The East Sea (Japan Sea) in change: a story of dissolved oxygen," Marine Technology Society Journal, vol. 33, no. 1, pp. 15-22, 1999.

[15] K. Keller, R. D. Slater, M. Bender, and R. M. Key, "Possible biological or physical explanations for decadal scale trends in North Pacific nutrient concentrations and oxygen utilization," Deep-Sea Research Part 2, vol. 49, no. 1-3, pp. 345-362, 2002.

[16] T. Ono, T. Midorikawa, Y. W. Watanabe, K. Tadokoro, and T. Saino, "Temporal increases of phosphate and apparent oxygen utilization in the subsurface water of western subarctic Pacific from 1968 to 1998," Geophysical Research Letters, vol. 28, no. 17, pp. 3285-3288, 2001.

[17] Y. W. Watanabe, T. Ono, A. Shimamoto, T. Sugimoto, M. Wakita, and S. Watanabe, "Probability of reduction in the formation rate of the subsurface water in the North Pacific during the 1980s and 1990s," Geophysical Research Letters, vol. 28, no. 17, pp. 32893292, 2001.

[18] S. Emerson, S. Mecking, and J. Abell, "The biological pump in subtropical North Pacific Ocean: nutrient sources, Redfield ratios, and recent changes," Global Biogeochemical Cycles, vol. 15 , no. 3, pp. 535-554, 2001.

[19] G. Shaffer, O. Leth, O. Ulloa et al., "Warming and circulation change in the eastern South Pacific Ocean," Geophysical Research Letters, vol. 27, no. 9, pp. 1247-1250, 2000.

[20] N. L. Bindoff and T. J. McDougall, "Decadal changes along an Indian Ocean section at $32^{\circ} \mathrm{S}$ and their interpretation," Journal of Physical Oceanography, vol. 30, no. 6, pp. 1207-1222, 2000.

[21] N. L. Bindoff, J. Willebrand, V. Artale et al., "Observations: oceanic climate change and sea level," in Climate Change 2007: The Physical Science Basis, S. Solomon, D. Qin, M. Manning et al., Eds., Contribution of Working Group 1 to the 4th Assessment Report of the Intergovernmental Panel on Climate Change, Cambridge University Press, Cambridge, UK, 2007.

[22] R. R. Stickney, Encyclopedia of Aquaculture, John Wiley \& Sons, New York, NY, USA, 2000.

[23] P. B. Moyle and J. J. Cech, Fishes: An Introduction to Ichthyology, Prentice Hall, Englewood Cliffs, NJ, USA, 5th edition, 2004.
[24] J. P. Gattuso and R. W. Buddemeier, "Calcification and $\mathrm{CO}_{2}$," Nature, vol. 407, no. 6802, pp. 311-313, 2000.

[25] C. D. G. Harley, A. R. Hughes, K. M. Hultgren et al., "The impacts of climate change in coastal marine systems," Ecology Letters, vol. 9, no. 2, pp. 228-241, 2006.

[26] E. A. Ainsworth and S. P. Long, "What have we learned from 15 years of free-air $\mathrm{CO}_{2}$ enrichment (FACE)? A meta-analytic review of the responses of photosynthesis, canopy properties and plant production to rising $\mathrm{CO}_{2}$," New Phytologist, vol. 165, no. 2, pp. 351-372, 2005.

[27] Y. Shirayama and H. Thornton, "Effect of increased atmospheric $\mathrm{CO}_{2}$ on shallow water marine benthos," Journal of Geophysical Research C, vol. 110, no. 9, Article ID C09S08, pp. 1-7, 2005.

[28] World Health Organization, Coastal and Fresh Waters, vol. 1 of Guidelines for safe Recreational Water Environments, WHO, 2003.

[29] G. P. Harris, "Biogeochemistry of nitrogen and phosphorus in Australian catchments, rivers and estuaries: effects of land use and flow regulation and comparisons with global patterns," Marine and Freshwater Research, vol. 52, no. 1, pp. 139-149, 2001.

[30] ANZECC/ARMCANZ, "Australian and New Zealand Guidelines for Fresh and Marine Water Quality," 2000, http://www .ea.gov.au/water/quality/nwqms/\#quality.

[31] V. N. De Jonge, M. Elliott, and E. Orive, "Causes, historical development, effects and future challenges of a common environmental problem: eutrophication," Hydrobiologia, vol. 475476, no. 1, pp. 1-19, 2002.

[32] C. A. Almeida, S. Quintar, P. González, and M. A. Mallea, "Influence of urbanization and tourist activities on the water quality of the Potrero de los Funes River (San Luis-Argentina)," Environmental Monitoring and Assessment, vol. 133, no. 1-3, pp. 459-465, 2007.

[33] S. Tanaka, S. Satoh, S. Kawagishi, T. Ishikawa, Y. Yamamoto, and G. Asano, "Sand transport mechanism in Ishikawa coast," Proceedings of Coastal Engineering, vol. 44, pp. 661-665, 1997 (Japanese).

[34] M. Yuhi, "Impact of anthropogenic modifications of a river basin on neighboring coasts: a case study," Journal of Waterway, Port, Coastal and Ocean Engineering, vol. 134, no. 6, pp. 336344, 2008.

[35] UNEP, "National reports on marine pollution preparedness and response in the Northwest Pacific Region," NOWPAP Publication no 4. UNEP/Regional Seas/IMO, 1998. 

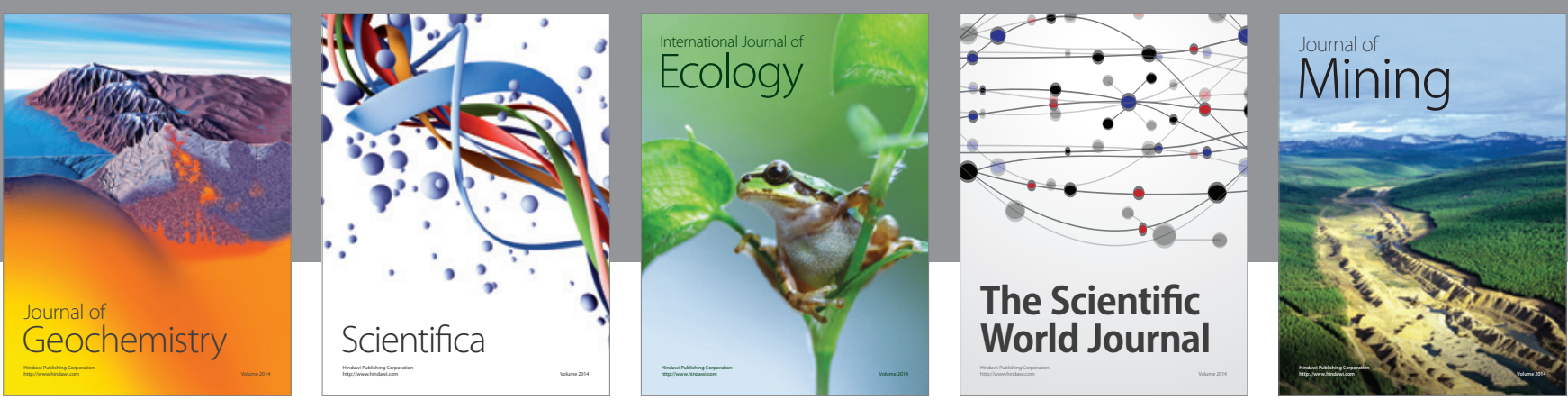

The Scientific World Journal
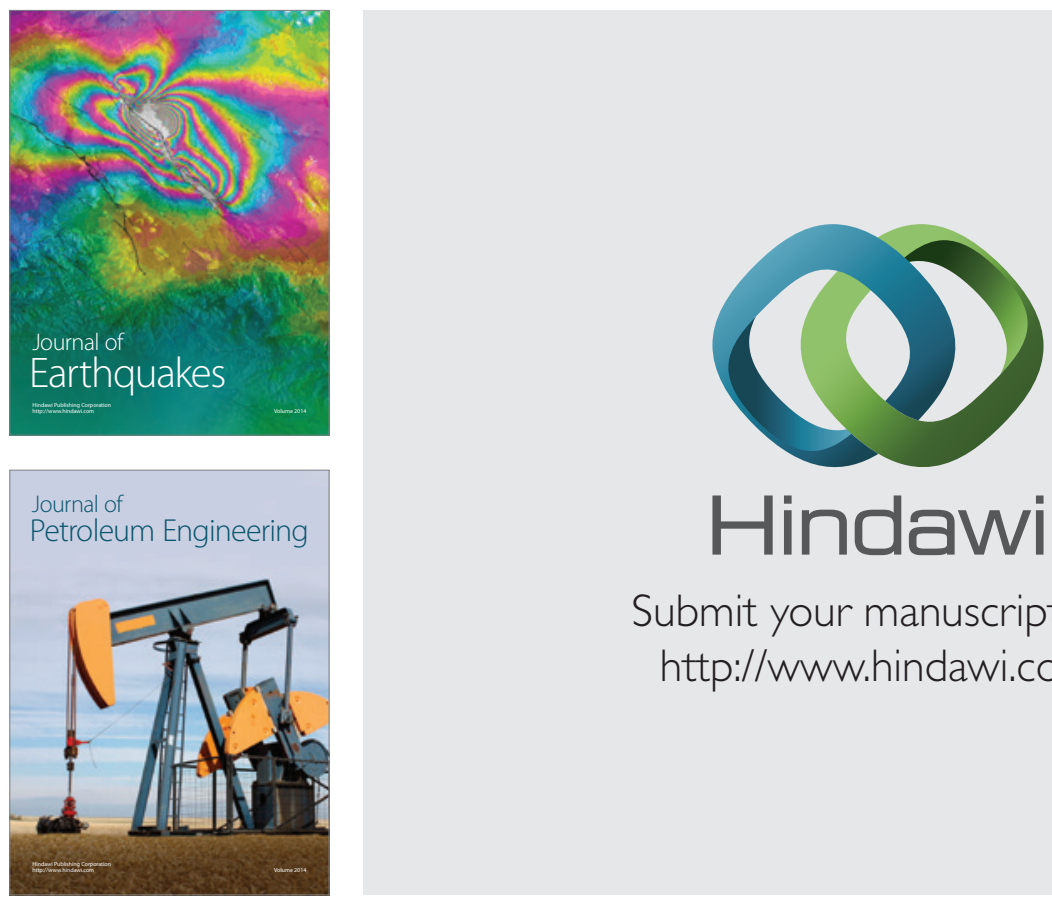

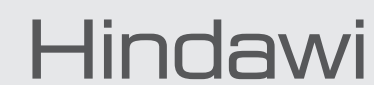

Submit your manuscripts at

http://www.hindawi.com
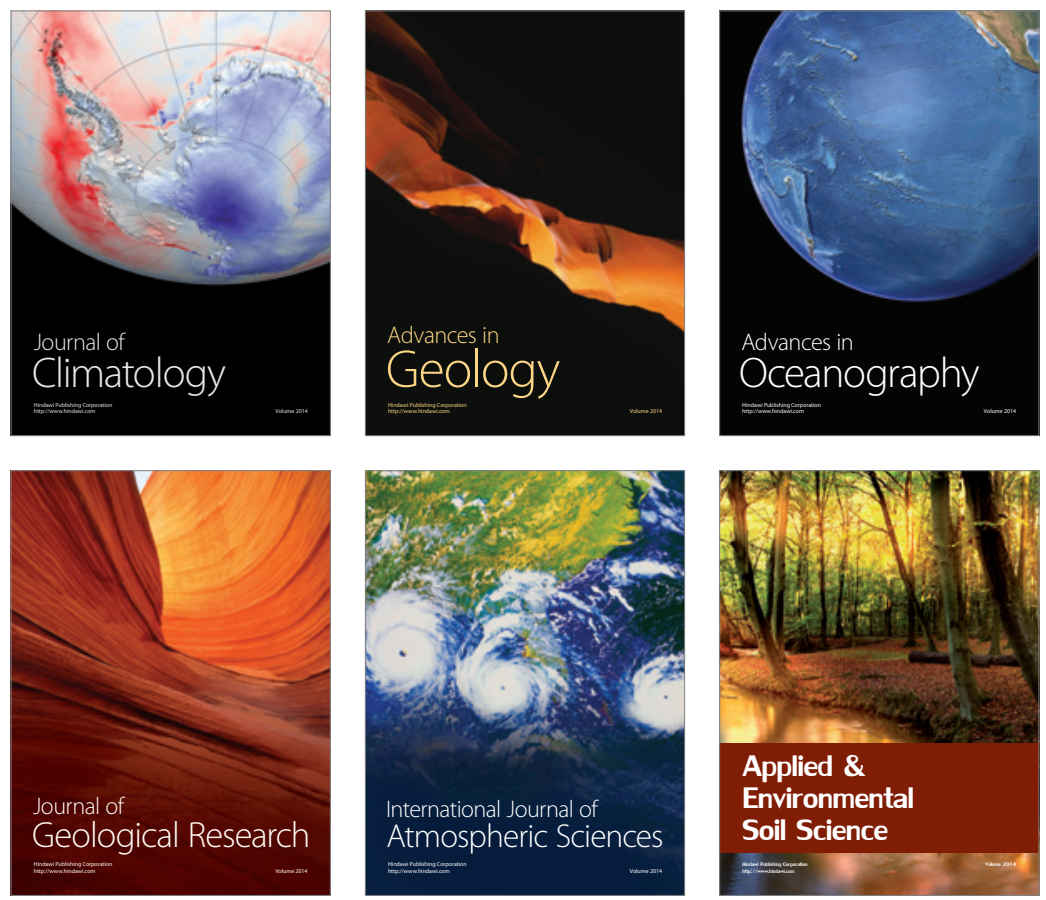
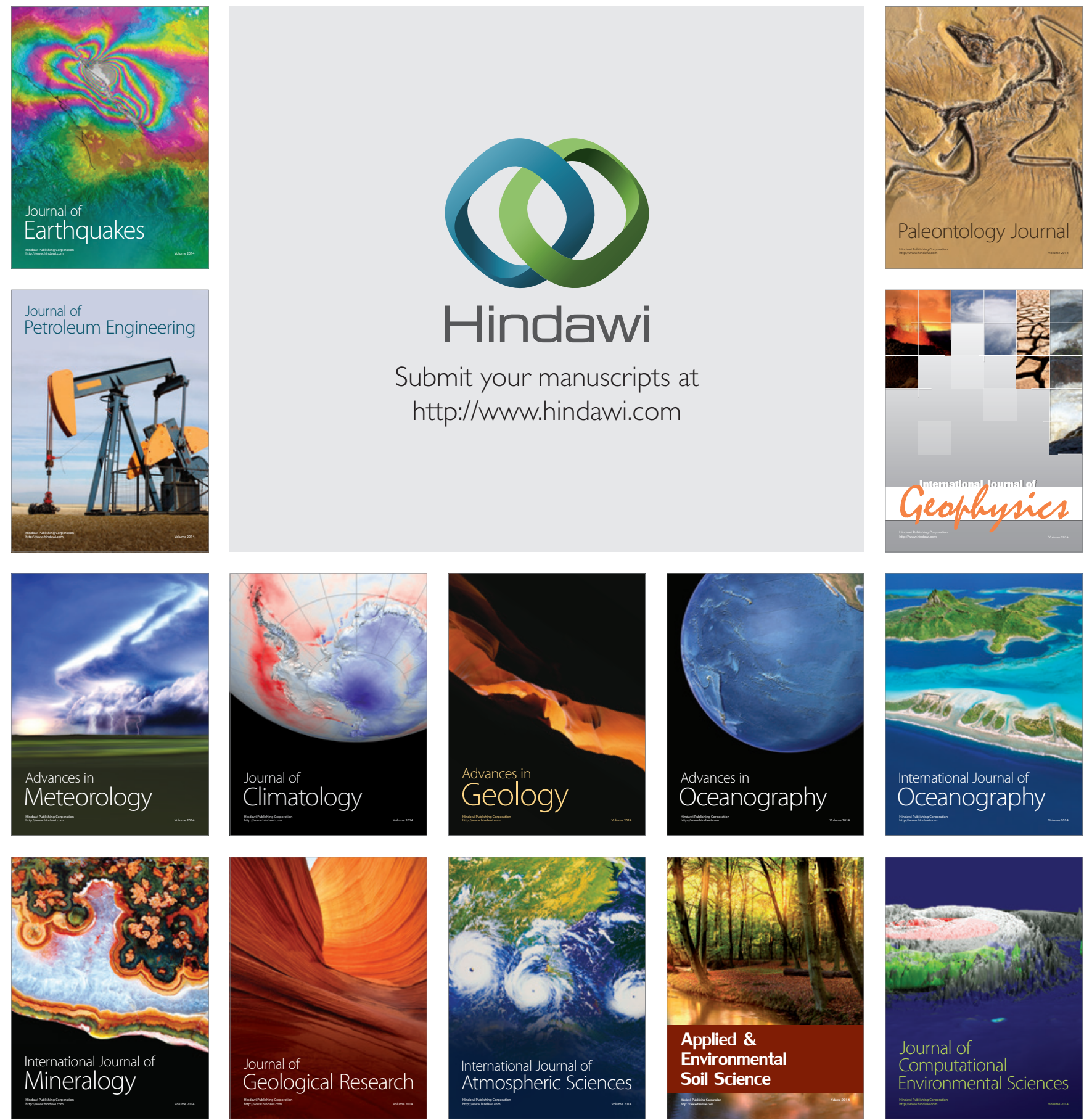